\title{
Impact of Institutional Ownership and Compensation on Investment Efficiency
}

\author{
Prita Esita $^{1}$, Muhammad Faisal ${ }^{2}$, Maulida Nurul Innayah ${ }^{3}$, Dwi Wirnani ${ }^{4}$, Bima \\ Cinintya Pratama 5 \\ \{pritaesita@ump.ac.id ${ }^{1}$ \}
}

Universitas Muhammadiyah Purwokerto ${ }^{1,3,4,5}$, Universitas YARSI ${ }^{2}$
Jalan Ahmad Dahlan, Dukuhwaluh, Banyumas, Jawa Tengah $1,3,4,5$
Menara YARSI, Jl. Letjend Suprapto No.Kav. 13, Kota Jakarta. ${ }^{2}$

\begin{abstract}
The purpose of the research is to study the effect of Institutional Ownership, Compensation on Investment Efficiency in companies which are listed on the Indonesian stock exchange (IDX) in 2017 . The population of the research are all listed companies in IDX for the period 2017. The sampling method of this research is used purposive sampling with a total sample of 532 companies which consist of financial industry, mining, and infrastructure, utilities and transportation. To test the hypothesis of this research, we use path analysis. The results show that Institutional Ownership, Compensation disclosure has a significant possitive effect on Investment Efficiency, which means. t he highest level of compensation and institutional ownership of the company, the more efficient the company is in disclosing its investment.
\end{abstract}

Keywords: Institutional Ownership; Compensation; Investment Efficiency

\section{Introduction}

Good governance implementing enterprises to protect shareholders from the opportunistic behavior of management and majority shareholders [1] . Recent several studies recommended and stated that the application of good governance will reduce the agency risk and reduce excess investment costs. Therefore, it is very important that companies maintain investment costs at a reasonable level because if it is too high, the company must release many potential investments [1].

Investment is an activity carried out by enterprises to support company's operational activities which then will benefit the company[2]. In order for get more benefits, the manager must be able to take decisions of investment efficiency. Investment efficiency is the company's main goal which the investments will be useful in the future. The reason researchers use investment efficiency as the dependent variable is based on with agency theory, that the efficiency of investment will be a bridge that can reduce the opportunistic behavior of management and make investment efficient.

To achieve efficiency, investments must be made in accordance with the needs [3]. Investment is related to the activities of withdrawing sources of funds used for the procurement of capital goods now. With capital goods, it is expected to produce a flow of new products in the future. Investment is needed to supporting the operational activities of an entity [4]. In order to investment get beneficial for the company, it needs efficiency in investing. Investment efficiency is an activity related to how well the company invests its assets. Investment efficiency can also be used as a measure of company performance where higher investment efficiency signifies more effective use of assets and optimizes current company performance[5]. 
Companies with good performance and can achieve investment optimally to avoid companies in a state of overinvestment and underinvestment. Both are conditions or circumstances where the company is inefficient in investing.

In this research institutional ownership and compensation are factors that will influence investment efficiency. Institutional ownership is ownership of shares of companies owned by insurance companies, banks and investment companies [6]. The advantage of institutional ownership is the supervision of investments provided on an ongoing and professional basis, the potential for fraud on what company managers do can be reduced [7]. Executive compensation is one of the most debated topics and has been the basis of much research since 1990 in developed countries, for example the United States and Britain [8]. In addition, in mass media such as newspapers or magazines, executive compensation is a major topic in business life.

\section{Literature Review}

\subsection{Agency Theory}

Agency theory is related to corporate governance where this theory isectly related between principals and agents [9]. The role of agency theory is to provide individual capabilities (both principals and agents) in efforts to improve performance and evaluation in the decisions taken and in evaluating the decisions taken. Consistent with this definition, most previous research uses agency theory as a perspective under the assumption that a decision will be carried out optimally by minimizing agency costs. The company will implement governance mechanisms to protect shareholders from opportunistic behavior of managers and in certain cases the majority shareholder [1].

To understanding the detail of cost of equity, this also reflects the optimization of the desired capital structure. The cost of equity related and reflects the company's long-term investment decisions [10]. Optimal equity costs will provide maximum benefits so that the level of corporate investment can be accounted for.

\subsection{Ownership and Efficiency Investment}

Institutional ownership is a mechanism to reduce conflicts of interest between managers and shareholders [11]. The ownership structure is shown from the size of the leadership of a company by the owner of the company. Outsiders who invest their funds in the company are considered as owners of the company who have certain authority in the company. This owner then appoints a manager called a company manager whose job is to operate the company's daily activities[12].

Institutional ownership shows how much ownership is owned by outsiders. Institutional investors whose investment capital is obtained from public funds play an active role in overseeing the company's performance. Institutional ownership can also reduce agency costs, because an effective oversight process by institutional parties causes the use of debt to decrease [13].

Research conducted by Ali, [14]states that there is an influence between institutional ownership on the efficiency of corporate investment. The higher percentage of institutional ownership indicates a better and more stringent monitoring process carried out by other institutions so that it will have an impact on better company performance and more neatly arranged, no exception in the investment efficiency of the company concerned. 


\section{H1. Institutional ownership has a positive effect on investment efficiency}

\subsection{Executive Compensation and Investment Efficiency}

In a balance between goals and expectations, the need for a mobilizer or reward that will provide hope of benefits for employees [15]. Compensation gives an influence in the organization to work optimally in the company that is being run. Compensation received by executives can affect the performance of these executives in running the company's performance.

Chen's research, 2017 revealed that providing executive compensation would better align the interests of managers and shareholders and improve company performance such as investment efficiency [5]. Previous research has examined the effect of compensation for top managers on firm performance in developed markets. Executive compensation options provide improvements with better investment efficiency in the United States [16].

H2. Executive Compensation has a positive effect on Investment Efficiency

\section{Method}

The sample in this research is all companies listed on the Indonesia Stock Exchange in 2017 . This study uses companies listed on the IDX because these companies have an obligation to submit financial reports or annual reports to outside parties, especially to the stakeholders. And for sampling in this study using non random sampling techniques, namely sampling techniques that do not provide equal opportunities or opportunities for each element or member of the population to be selected as a sample [17]. Based on the predetermined sample selection criteria, a total sample of 532 observants was obtained. The 532 companies included 63 manufacturing companies, 75 financial companies, 45 oil, gas \& fuel consumption companies, and others.

The dependent variable capital structure in this study was measured by:

Information :

$$
\begin{gathered}
\text { Investasi }=\beta_{0}+\beta \text { Sales Growth }+e \\
\frac{\Delta A T L}{T A_{t-1}}=\beta_{0}+\beta \text { Sales Growth }+e
\end{gathered}
$$

\footnotetext{
Investasi $\quad=$ Change in the total non-current assets of company $\mathrm{i}$ in period $\mathrm{t}$ divided by lagged total assets .

Sales Growth, $\quad=$ percentage of changes in company sales $\mathrm{i}$ from period $\mathrm{t}-1$ to t.
}

First variable independent is institutional ownership that is measured by :

$$
\text { Institutional Ownership = Presentation of institusional ownership stock }
$$

Second variable independent is compensation that is measured by :

$$
\text { Compensation }=\text { Total of Excecutive Compensation }
$$

This following models in this research : 
Information :

$$
I E=\alpha+\beta 1 O W N+\beta 2 C O M P+\varepsilon
$$

IE $=$ Investment Efficiency

OWN = Institusional Ownership

COMP $=$ Excecutive Compensation

\section{Results And Discussion}

Table 1. provides a descriptive statistical description of each variable, especially the minimum, maximum, average, standard deviation, and the number of companies observed.

Table 1. Descriptive Sample Statistics

\begin{tabular}{cccccc}
\hline $\begin{array}{c}\text { Research } \\
\text { Variable }\end{array}$ & Total & Minimum & Maximum & Average & $\begin{array}{c}\text { Standard } \\
\text { Deviation }\end{array}$ \\
\hline Ownership & 510 & 16 & 95 & 54,685 & 14,159 \\
Compensation & 510 & 10.810 .500 & 160.000 .000 .000 & $\begin{array}{c}15.314 .900 .000, \\
438\end{array}$ & $\begin{array}{c}26.200 .000 .129 \\
, 286\end{array}$ \\
$\begin{array}{c}\text { Investment } \\
\text { Efficiency }\end{array}$ & 510 & 0,004 & 0,250 & 0,095 & 0,056 \\
\hline
\end{tabular}

\subsection{Classic Assumption Test}

Table 2. Normality Test Using the Kolmogorov-Smirnov Test

\begin{tabular}{lr}
\hline \multicolumn{2}{c}{ One-Sample Kolmogorov-Smirnov Test } \\
\hline \multicolumn{2}{c}{ Unstandardized Residual } \\
\hline $\mathrm{N}$ & 1,030 \\
Kolmogorov-Smirnov Z & 0,239 \\
Asymp. Sig. (2-tailed) & \\
\hline a. Test distribution is Normal.
\end{tabular}

This research fulfills all the classical assumption tests. In this study the KolmogorovSmirnov normality test is 1.030 and the significance is 0.239 , the significance value is well above 0.05 , which means that the residual data are normally distributed and the regression model can be used for further testing. In addition, there was no heteroscedasticity and multicollinearity between independent variables did not occur. 
Histogram

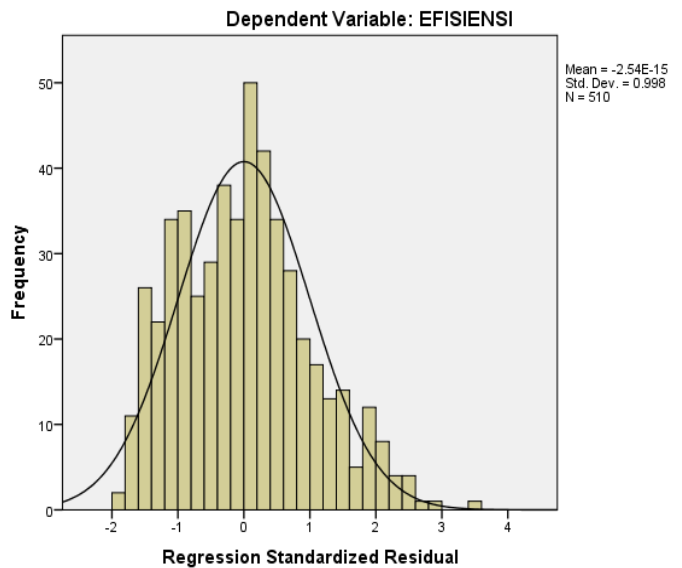

Fig.1. Normality Results using a Histogram chart

Normal P-P Plot of Regression Standardized Residual

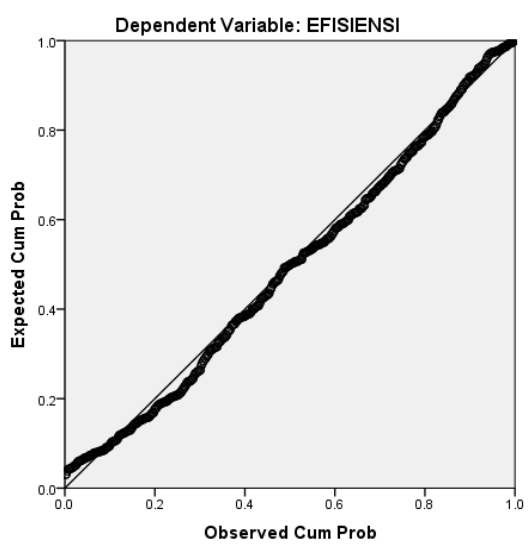

Fig.2 . Normality Test Results with the P-Plot Diagram

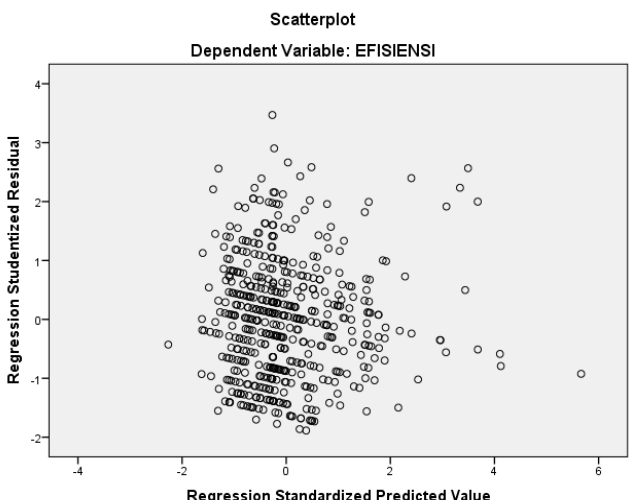

Fig.3. Heterokedasticity Test Results Using Scatterplot 
Table 3. Heteroscedasticity Test Results With Glejser Test

\begin{tabular}{lrr}
\hline \multicolumn{3}{c}{ Coefficients } \\
\hline & t-value & significance \\
\hline (Constant) & 8,259 & 0,000 \\
Institutional Ownership & $-0,897$ & 0,370 \\
Compensation & 0,923 & 0,356 \\
\hline \multicolumn{1}{c}{ Dependent Variable: Abs_res } & \\
\hline
\end{tabular}

\subsection{Hypothesis Testing}

a) Regression Analysis

$$
. I E=\alpha+\beta 1 O W N+\beta 2 C O M P+\varepsilon
$$

1. F-test

The $\mathrm{F}$ test basically shows whether all the independent variables influence simultaneously or together on the dependent variable.

Table 4. Results of the Effects of the F Test

\begin{tabular}{ccccc}
\hline F-count & F-table & Significance & Testing Criteria & Information \\
& & & & \\
\hline 10,077 & 3,04 & 0,000 & $\mathrm{p}<0,05$ & Signifikan \\
\hline
\end{tabular}

In this test Institutional Compensation and Ownership as an independent variable and Investment Efficiency as the dependent variable. From the table above shows that the significant level of 0,000 . Thus, it can be concluded that the value of 0,000 is less than a significant level of 0.05, which means that Compensation and Institutional Ownership has a significant effect on Investment Efficiency. Anova test results in Table 4.7 obtained the calculated F value of 10.128 The calculated $\mathrm{F}$ value is greater than the $\mathrm{F}$ value of table 3.04 so that it can be concluded that the Compensation and Institutional Ownership variables have a significant effect on Investment Efficiency

2. T-test

$\mathrm{T}$ test or partial test is a hypothesis test that is used to measure how far the influence of one independent variable individually in explaining the variation of the dependent variable namely Compensation with Investment Efficiency, Institutional Ownership with Investment Efficiency

Table 5. Results of the Effects of $t$ Test

\begin{tabular}{|c|c|c|c|c|}
\hline \multirow[t]{2}{*}{ Model } & \multicolumn{2}{|c|}{$\begin{array}{c}\text { Unstandardized } \\
\text { Coefficients }\end{array}$} & \multirow[t]{2}{*}{ t-value } & \multirow[t]{2}{*}{ Significance } \\
\hline & B & Std. Error & & \\
\hline (Constant) & 0,063 & 0,010 & 6,605 & 0,000 \\
\hline $\begin{array}{l}\text { Institutional } \\
\text { Ownership }\end{array}$ & 0,001 & 0,000 & 3,315 & 0,001 \\
\hline Compensation & $3.800 \mathrm{E}-013$ & 0,000 & 2,846 & 0,005 \\
\hline
\end{tabular}


The first hypothesis in this study is the effect of Institutional Ownership on Investment Efficiency. From table 5 above, it is known that the test results show a significance level of 0.001 , the value is less than the significant probability value of 0.05 , it can be concluded that Institutional Ownership influences Investment Efficiency.

The second hypothesis in this study is the effect of Compensation on Investment Efficiency. From table 4.9 above it is known that the test results show a significance level of 0.005 , the value is less than the significant probability value of 0.05 , it can be concluded that Compensation affects the Investment Efficiency.

\section{Coefficient of Determination}

To find out how far the ability of the model in explaining the variation of the dependent variable, the coefficient of determination test is performed. The coefficient of determination (R2) basically measures how far the model's ability to explain the variation of the dependent variable. The greater the coefficient of determination, the greater the ability of the independent variable in explaining the dependent variable.

Table 6. Result of Coefficient of Determination

\begin{tabular}{cccc}
\hline $\mathbf{R}$ & $\boldsymbol{R}$ Square & Adjusted $\boldsymbol{R}$ Square & Std. Error of the Estimate \\
\hline 0,196 & 0,038 & 0,034 & 0,054 \\
\hline
\end{tabular}

From Table 6 above it is known that the coefficient of determination (R square) of 0.038 means that $3.8 \%$ of the variation in efficiency can be explained by the two independent variables Compensation and Institutional Ownership. While $96.2 \%$ is explained by causes outside the model .

Based on the explanation above, it can be concluded that the independent variable Institutional Ownership and Compensation has a positive effect on Investment Efficiency .

\subsection{Institutional Ownership and Investment Efficiency}

The results of testing the first hypothesis in table 5 show that the coefficient of determination is 0.001 and the value of $t$ arithmetic $>t$ table $(3.315>1.974)$. The results of this test can be interpreted that the large value of the variable institutional ownership affects the investment efficiency so that it can be interpreted the higher institutional ownership in a company, the higher the efficiency level of an investment disclosed, conversely the lower the institutional ownership in a company, the lower also the level of investment efficiency disclosed. This shows that companies that have a higher level of institutional ownership will utilize investment activities as efficiently as possible. These results support the results of testing the hypothesis that the institutional side can intervene in the managerial party as the investment decision maker, because of the intervention that occurs it can cause investment decision making to be appropriate and efficient.

The results of this study are in line with research conducted by Chen [5], Biddle [18], which proves that institutional ownership has a significant positive effect on investment efficiency [18]. Institutions that act as investors have a good ability to oversee the development of company performance. The results of the influence of institutional ownership on investment efficiency in this study prove the truth of agency theory. Agency costs can be minimized through institutional ownership, where this type of ownership will provide more systematic and controlled supervision [19]. This happens because an increase in institutional ownership as a party that monitors the agent will reduce the impact of information asemtri that may only be obtained by the agents [20]. 


\subsection{Compensation and Efficiency Investment}

The second hypothesis in this study is that executive compensation has a positive effect on the efficiency of corporate investment. The results of testing the second hypothesis in table 4.9 show that the coefficient of determination is 3,800E-13 and the value of $t$ arithmetic $>t$ table $(2.846>1.974)$. The results of this test can be interpreted that the magnitude of the variable executive compensation affects the investment efficiency so that it can be interpreted the higher executive compensation in a company, the higher the level of efficiency of an investment disclosed, conversely the lower the executive compensation in a company, the lower also the level of investment efficiency disclosed. This shows that companies with higher executive compensation levels will make the most efficient use of investment activities.

The results of this study are in line with Zhang [15] conducted by which prove that compensation has a significant positive effect on investment efficiency [15]. The company's goal in motivating or motivating CEOs by giving compensation is to work better or harder than before to increase profits, increase CEO compensation, and at the same time, it can provide benefits to principals [21]. For this reason, contracts that align interests between the two parties are written by including a compensation feature, namely the principal writing a contract or agreement that allows management to obtain a share of the wealth when the value of the company increases.

\section{Conclusions}

The results of this study indicate that institutional ownership has a significantly positive effect on investment efficiency. The results of the influence of institutional ownership variables on investment efficiency variables prove the truth of the agency theory. Agency costs that may occur can be minimized through institutional ownership, where this type of ownership will provide more systematic and controlled supervision. The results of this study also indicate that compensation has a significant positive effect on Investment Efficiency. Executive compensation plays a role in correcting or overcoming moral hazard problems (manager opportunism) arising from low company ownership. By using stock options, limited shares, and long-term contracts, shareholders can motivate the CEO to maximize the value of the company by streamlining the level of investment efficiency in a company .

The limitation in this study lies in the level of R-Square which is quite low at $3.8 \%$ in model 1 and $1.9 \%$ in model 2 indicating other variables not used in this study have a greater influence on the dependent variable undertaken by this study

Based on the conclusions and limitations in this research, suggestions are proposed by the author, which is seen from the value of R Square reflects the factors others are not examined in this study. Next researcher consider other variables to the company's investment, such as the size, leverage and information asymmetry.

\section{Reference}

[1] M. A. Majeed, X. Zhang, and M. Umar, "Impact of investment efficiency on cost of equity: evidence from China," Journal of Asia Business Studies, vol. 12, no. 1. pp. 44-59, 2018, doi: 
10.1108/jabs-09-2015-0163.

[2] C. G. Gerald, Applied Analysis. Addison-Wesley Publishing Company, Singapore., 1978.

[3] Pidii, Potential and Investment Opportunities in Wakatobi Regency: "Becoming Prosperous and Competitive Maritime Regency." Pidii, 2019.

[4] Subramanyam, Investment Banking:Concepts, Analysis \& Cases. Tata McGraw-Hill Education, 2008.

[5] N. Chen, H.-C. Sung, and J. Yang, "Ownership structure, corporate governance and investment efficiency of Chinese listed firms," Pacific Accounting Review, vol. 29, no. 3. pp. 266-282, 2017, doi: 10.1108/par-12-2015-0046.

[6] S. Fung and S.-C. Tsai, "Institutional Ownership and Corporate Investment Performance," Canadian Journal of Administrative Sciences / Revue Canadienne des Sciences de l'Administration, vol. 29, no. 4. pp. 348-365, 2012, doi: 10.1002/cjas.1232.

[7] C. T. Bathala, K. P. Moon, and R. P. Rao, "Managerial Ownership, Debt Policy, and the Impact of Institutional Holdings: An Agency Perspective," Financial Management, vol. 23, no. 3. p. 38, 1994, doi: $10.2307 / 3665620$.

[8] M. S. Sirkin and L. K. Cagney, Executive Compensation. Law Journal Press, 2018.

[9] M.-L. Matthiesen and A. J. Salzmann, "Corporate social responsibility and firms' cost of equity: how does culture matter?," Cross Cultural \& Strategic Management, vol. 24, no. 1. pp. 105-124, 2017, doi: 10.1108/ccsm-11-2015-0169.

[10] W. F. Sharpe, "Investment Strategy for the Long Term," Handbook of Finance. 2008, doi: 10.1002/9780470404324.hof002011.

[11] Q. T. Tran, "Foreign ownership and investment efficiency: new evidence from an emerging market," International Journal of Emerging Markets, vol. 15, no. 6. pp. 1185-1199, 2020, doi: 10.1108/ijoem-07-2019-0573.

[12] D. C. Russell, "Self-Ownership as a Form of Ownership," Oxford Handbooks Online. 2016, doi: 10.1093/oxfordhb/9780199989423.013.31.

[13] F. Fauzia and E. Rahmawati, "Pengaruh Struktur Kepemilikan dan Mekanisme Corporate Governance terhadap Tingkat Kepatuhan Mandatory Disclosure Konvergensi IFRS : Studi Empiris pada Perusahaan Manufaktur yang Terdaftar di BEI 2012-2015," Reviu Akuntansi dan Bisnis Indonesia, vol. 1, no. 1. 2017, doi: 10.18196/rab.010104.

[14] A. Ali, T.-Y. Chen, and S. Radhakrishnan, "Corporate Disclosures by Family Firms," SSRN Electronic Journal. doi: 10.2139/ssrn.897817.

[15] K. Zhang, S. Y. Ji, and X. Zhang, "The Nature of Controlling Shareholders, Executive Compensation and Investment Efficiency: Data from Chinese Capital Markets," 2019 International Conference on Economic Management and Model Engineering (ICEMME). 2019, doi: 10.1109/icemme49371.2019.00117.

[16] N. Attig, O. Guedhami, and D. R. Mishra, "Multiple Large Shareholders, Control Contests, and Implied Cost of Equity," SSRN Electronic Journal. doi: 10.2139/ssrn.1282129.

[17] Sujoko and S. Sujoko, "Pengaruh Struktur Kepemilikan, Strategi Diversifikasi, Leverage, Faktor Intern Dan Faktor Ekstern Terhadap Nilai Perusahaan (Studi Empirik Pada Perusahaan Manufaktur Dan Non Manufaktur Di Bursa Efek Jakarta)," EKUITAS (Jurnal Ekonomi dan Keuangan), vol. 11, no. 2. p. 236, 2017, doi: 10.24034/j25485024.y2007.v11.i2.2236.

[18] G. C. Biddle, G. Hilary, and R. S. Verdi, "How Does Financial Reporting Quality Relate to Investment Efficiency?," SSRN Electronic Journal. doi: 10.2139/ssrn.1146536.

[19] "Agency theory," SpringerReference. doi: 10.1007/springerreference_5223.

[20] A. Elaoud and A. Jarboui, "Auditor specialization, accounting information quality and investment efficiency," Research in International Business and Finance, vol. 42. pp. 616-629, 2017, doi: 10.1016/j.ribaf.2017.07.006.

[21] C. Frydman and D. Jenter, “CEO Compensation.” 2010, doi: 10.3386/w16585. 